\title{
El recuerdo como un problema del espacio pictórico en los paisajes de Patricio Larrambebere*
}

\author{
María Guillermina Fressoli**
}

\begin{abstract}
Recibido: 2 de agosto de 2015
Evaluado: 19 de septiembre de 2015

Aceptado: 30 de septiembre de 2015
\end{abstract}

\section{RESUMEN}

Este artículo busca reflexionar sobre la forma que adquiere la configuración del recuerdo en la pintura de Patricio Larrambebere, prestando particular atención a los paisajes urbanos que el artista produce durante los últimos años de la década de los noventa. A partir del análisis exhaustivo de estas pinturas busco dar cuenta de las tensiones que esta obras plantean a su contemporaneidad, por cuanto son producidas en un momento histórico signado por el desarrollo y expansión de una cultura neoliberal que reconfigura las prácticas y espacios de Buenos Aires y sus alrededores.

En las obras seleccionadas se destaca un énfasis en la pintura como trabajo y registro documental, el progresivo repliegue de la representación de la figura humana y un proceso de abstracción que afecta a los paisajes urbanos que el artista elabora. Estos aspectos aportan a la constitución de una pintura de historia que se instala como acción de perdurabilidad frente a la desazón que produce la pérdida inminente de un espacio social y un sujeto histórico en crisis. En ese marco, el trabajo pictórico manifiesta un esfuerzo de retención/restitución de un espacio de experiencia, vinculado a los últimos destellos del Estado de Bienestar, que inexorablemente hacia fines de la década de

* Articulo de investigación. Este trabajo expone algunos de los resultados obtenidos en el desarrollo de tesis doctoral. Estos estudios fueron realizados con beca del Consejo Nacional de Investigaciones Científicas y técnicas (Conicet). Cómo citar este artículo: Fressoli, M.G. (2016). El recuerdo como un problema del espacio pictórico en los paisajes de Patricio Larrambebere. Hallazgos, 13(25), 133-156 (doi: http://dx.doi.org/10.15332/ s1794-3841.2016.0025.06).

** Doctora en Filosofía y Letras, Área Historia y Teoría del arte, de la Universidad de Buenos Aires (Argentina). Becaria posdoctoral del Conicet. Docente en la Universidad Nacional Tres de Febrero (Argentina). Correo electrónico: guillefressoli@gmail.com 
los noventa se pierden. Esto explica la figuración cada vez más precaria que en el obrar del artista adquieren diferentes lugares emblemáticos para la memoria colectiva, como clubes, estaciones ferroviarias, cines, radios o galerías comerciales, entre otros.

Palabras clave: arte y memoria, pintura contemporánea argentina, neoliberalismo, realismo, arte e historia. 


\section{Memory as a pictorial space problem in Patricio Larrambebere's landscapes}

Received: August 2, 2015 Evaluated: September 19, 2015 Accepted: September 30, 2015

\section{Abstract}

This article aims to study about memory configuration in Patricio Larrambebere's landscape paintings that were produced during the last years of the 90s. From the analysis of these works, my proposal is to realize about tensions which these paintings produce to its contemporary time. Considering these works are made in a historical moment marked by the development and expansion of a neoliberal culture, which reconfigures the socials practices and public spaces of Buenos Aires and its surroundings.

The works selected for this article shows: a) an emphasis on painting as work and also as a document; b) the gradual disappearance of the human figure; and c) a process of abstraction that affect the paintings.

I consider that these aspects contributed to the creation of a contemporary historical painting. The use of this kind of painting is an action against the uneasiness that produces the imminent loss of a public space and a historical subject in crisis.

In this context, the act of painting manifests an effort in order to keep a space of experience which was desappearing at that time. This loss is related with the last traces of the Welfare State in the country. This situation explains the figurative precariousness which the artist used to represent different social emblematic buildings and landscapes such as clubs, railway stations, cinemas, radios or traditional markets.

Keywords: Art and memory, argentinean contemporary painting, neoliberalism, art and history. 


\section{A lembrança como um problema do espaço pictórico nas paisagens de Patrício Larrambebere}

\section{Resumo}

Este artigo busca refletir sobre a forma da configuração da meRecebido: 2 de agosto de 2015 mória na pintura de Patrício Larrambebere, prestando particuAvaliado: 19 de setembro de 2015 lar atenção às paisagens urbanas que o artista produz durante o final da década de noventa. A partir da análise exaustiva de suas pinturas, busca-se compreender as tensões que estas obras implicam atualmente, por serem produzidas em um momento histórico marcado pelo desenvolvimento e expansão de uma cultura neoliberal que reconfigura as práticas e espaços de Buenos Aires e seu entorno.

Nas obras selecionadas para este trabalho damos ênfase à pintura como trabalho e registro documental, o progressivo desdobramento da representação da figura humana e o processo de abstração que afeta as paisagens urbanas elaboradas pelo artista. Estes aspectos constituem uma pintura histórica que se instala como ação perdurável frente a inquietação produzida pela perda eminente de um espaço social e da crise do sujeito histórico. Neste marco, o trabalho pictórico manifesta um esforço de retenção/ restituição de um espaço de experiência, vinculado aos últimos lampejos do Estado do Bem Estar, perdido ao fim da década de noventa. Isto explica a configuração cada vez mais precária que a obra do artista adquire em diferentes lugares para a memória coletiva, como clubes, estações ferroviárias, cinema, rádios ou galerias comerciais, entre outros.

Palavras-chave: arte e memória, pintura contemporânea argentina, neoliberalismo, realismo, arte e história. 
"La edad de la anti-representación no es la edad de lo irrepresentable.

Es la del gran realismo"

Jacques Rancière

\section{INTRODUCCIÓN}

Este artículo busca reflexionar sobre la forma que adquiere la configuración del recuerdo en la pintura de Patricio Larrambebere, prestando particular atención a los paisajes urbanos que el artista produce durante los últimos años de la década de los noventa ${ }^{1}$. A partir del análisis exhaustivo de sus pinturas busco dar cuenta de las tensiones que esta obras plantean a su contemporaneidad, por cuanto son producidas en un momento histórico signado por el desarrollo y expansión de una cultura neoliberal que reconfigura las prácticas y espacios de Buenos Aires y sus alrededores.

En las obras seleccionadas para se destaca un énfasis en la pintura como trabajo y registro, el progresivo repliegue de la representación de la figura humana y un proceso de abstracción que afecta a los paisajes urbanos que el artista elabora. Estos aspectos aportan a la constitución de una pintura de historia que se instala como acción de perdurabilidad frente a la desazón que produce la pérdida inminente de un espacio social y un sujeto histórico en crisis. En ese marco, el trabajo pictórico manifiesta un esfuerzo de retención/restitución de un espacio de experiencia, vinculado a los últimos destellos del Estado de Bienestar, que inexorablemente hacia fines de la década de los noventa se

1 Para más información sobre este artista véase http://www. patriciolarrambebere.org/ pierden $^{2}$. Esto explica la figuración cada vez más precaria que en el obrar del artista adquieren diferentes lugares emblemáticos para la memoria colectiva, como clubes, estaciones ferroviarias, cines, radios o galerías comerciales entre otros.

\section{LA CONFORMACIÓN DE UN MUNDO VISUAL}

Con el fin de comprender cómo se conforman las representaciones que el artista elabora, propongo inicialmente en este apartado explorar las fuentes visuales que nutren su proceso creativo.

En sus primeros años de trabajo, se observa un gusto por los procedimientos del arte pop británico. Esta escuela fue precursora en la reelaboración de los primeros usos que la pintura hizo de la fotografía a partir de la obra de Francis Bacon ${ }^{3}$. En la obra de

2 El modelo político y social denominado Estado de Bienestar se desarrolla en Argentina durante 1945 y 1973. En esos años el país creció en su capacidad industrial, infraestructura y seguridad social. Desde las década de los setenta este modelo se retrae y deteriora progresivamente. Durante la década de los noventa la crisis de dicho modelo se intensifica, merced del avance del modelo neoliberal. Ahora bien, si por un lado el modelo neoliberal supuso un cambio radical en las prácticas y consumos de la ciudadanía, en la ciudad las marcas espaciales del viejo modelo persistían: clubes sociales, arquitecturas sindicales, así como marcas en las veredas y fachadas de edificios correspondientes a las empresas estatales en proceso de privatización (Entel, YPF. Gas del Estado, entre otras). Estos restos y pervivencias fueron registrados y utilizados por un conjunto de artistas, entre los que podemos incluir la producción de Patricio Larrambebere, que junto a otros actores de la época alertaban sobre este proceso de crisis (Cf. Fressoli, 2015).

3 La singularidad de esta escuela es destacada por Simon Wilson (1975). Según el autor, Bacon proveyó al arte pop de dos particularidades. La primera vinculada al uso de la fotografía en la pintura, lo que en Bacon se manifiesta a través del uso como fuentes de sus pinturas de fotogramas que corresponden al filme El acorazado Potekim, o las series fotográficas de Eadweard Muybriodge, entre otros. La segunda particularidad que destaca Wilson es la referencia a la historia del arte, que en el caso de Bacon se expresa en su constante referencia a las pinturas de Velásquez. Retomarán esta 
Larrambebere lo fotográfico adquirirá distintos usos en las diferentes series, primero sujeto al collage como principio constructi$\mathrm{vo}^{4}$, luego vinculado al planteo estructural de diversos paisajes.

A partir de 1997, se observan referencias al trabajo de Pablo Suárez. Con particular interés en una serie que este pintor realiza entre 1975 y 1983, donde sus pinturas representan detalles de rincones domésticos desolados. En estos trabajos convergen diversas referencias a la tradición local, como Fortunato Lacámera, Alfredo Gramajo Gutiérrez y Molina Campos, que también dejarán su impronta en Larrambebere durante el período en el que estudia con Suárez ${ }^{5}$.

Las obras que Suárez realiza en este momento se caracterizan por una acepción plana del espacio y el uso de sombras nítidas y homogéneas, que se vinculan a los modos de la pintura quattrocentista. Estos aspecto, junto a la simpleza de la composición que se reduce a la articulación de unos pocos elementos, entre los que se excluye la figuración humana, serán fundamentales para las representaciones de paisajes que Larrambebere realiza a partir de 1997. Cabe destacar, sin embargo, que en el trabajo de

tendencia dentro del pop británico artistas como Richard Halmiton o Peter Blake, entre otros.

4 Simón Marchán Fiz identificó una nueva acepción del collage a la que denominó principio collage, refiriendo ya no solo al encuentro de materiales diversos, sino también "a un proceso operante en expansión hacia la contemporaneidad del arte". De este modo, el autor refiere la trascendencia de la técnica collage tal como esta fuera comprendida en sus orígenes cubistas para devenir un principio constructivo de las obras, y en tal sentido amplía sus posibilidades creativas. Así, el autor comprende el collage como la irrupción práctica y teórica de factores extraartísticos en la obra de arte (Marchán Fiz, 1997, p. 159)

5 En el año 1996 Patricio Larrambebere asiste a los talleres que Pablo Suarez dicta en la Escuela Superior de Bellas Artes Ernesto de la Cárcova.
Larrambebere los motivos se desplazan a la consideración del espacio público, frente a la intimidad doméstica que instalaban las obras de Suárez, realizadas en otras condiciones de producción ${ }^{6}$. En los desplazamientos del sistema representativo de maestro-discípulo varían las cualificaciones históricas que en cada caso adquiere la ausencia a través de los materiales que componen las obras.

Finalmente, en los trabajos que Larrambebere realiza hacia 1999, es posible observar el ingreso de cierta precariedad y desmaterialización en el modo de pintar, que recuerda a los trabajos de Miguel Diomede ${ }^{7}$. Dicho artista exhibe en sus pinturas una precariedad que es impulsada por la poca carga de color y el carácter inacabado que voluntariamente exhiben sus trabajos.

En los siguientes apartados observaremos cómo las referencias visuales consignadas se reconfiguran en la obra de Larrambebere hacia el registro de un suceso histórico contemporáneo que de modo singular compromete al recuerdo de quién especta.

\section{Del collage al paisaje PICTÓRICO}

Hacia 1996 el artista plantea en sus composiciones diversas representaciones de paisajes ferroviarios que, de acuerdo con

6 Estas obras de Suárez se producen en los años de la última dictadura militar argentina, momento en el que el artista se recluye a trabajar en el campo y reflexiona sobre la tradición del paisaje en la pintura nacional.

7 Miguel Diomede (1902-1974) fue un importante pintor dentro de la historia de la pintura argentina. En sus trabajos se distinguen retratos, naturalezas muertas y paisajes locales, particularmente del barrio de la boca. Sus obras integran actualmente el acerbo del Museo Nacional de Bellas Artes y Museo de Bellas Artes de la Boca entre otros. 
su testimonio, comenzaban por entonces a desaparecer. A través de la pintura el artista intentará retener un espacio que se ensambla con un pasado común que es, a su vez, signo de su infancia (debido a que diariamente tomaba el tren para ir al colegio y la estación Coghlan, ubicada en su barrio, era su espacio de vivencia cotidiano). El pasado común al que me refiero y que se reitera durante este periodo en su obra se haya directamente vinculado a una acepción de Estado progresivamente en deterioro en el momento en que estas obras se producen. Sobre esta búsqueda orientada a la representación del paisaje urbano el artista relata:

Esto tiene que ver con los afectos, con esto de que a partir del secundario tenía una conexión con el espacio público y con el espacio ferroviario en particular $[\ldots]$

Yo lo que estaba viendo es que, a partir de la concesión de los servicios ferroviarios estatales a las empresas como TBA, todo este tipo de instalaciones ferroviarias estaban en peligro de desaparición [...] a partir también de la desaparición de quienes cuidaban eso. La historia oral [...] de quienes sabían de qué se trataba este tipo de edificios $\mathrm{y}$ todo este sistema tecnológico. El que a su vez era catalogado de obsoleto por quienes quisieron hacernos ir a la luna con el estómago vació en los años 90, quienes lo iban a desdeñar y despreciar.

Todo este registro de la pintura como documento del paisaje ferroviario tiene que ver, en cierta medida, con la intuición de la desaparición de todo eso, no solo del paisaje sino también de la gente que tenía que ver con ese paisa-

je. (Larrambebere, noviembre de 2012.

Comunicación personal)

Las nuevas búsquedas que orientan el trabajo del pintor hacia la representación del paisaje ferroviario urbano irán acompañadas de un cambio en los modos de componer, los cuales se desplazan del collage - como principio constructivo - hacia la tradición del paisaje como género autónomo de la pintura.

Para estudiar este cambio he seleccionado tres obras: Dr. L. M. Drago, con barreras averiadas (imagen 1); Luis María Saaevedra (imagen 5) y Puente Alsina (imagen 6). Estas pinturas permiten distinguir un momento de transición en los procedimientos del pintor, lo que a su vez comportará un cambio en los modos como su obrar configura el recuerdo.

Estos tres trabajos muestran una unidad en la elección del tema, el cual considera el espacio ferroviario urbano; al mismo tiempo que se observa un progresivo desplazamiento de la figura humana que dejará definitivamente de ser representada en las composiciones siguientes.

La elección del paisaje es portadora de tradiciones que se ensamblan con inquietudes del artista en su contemporaneidad. El paisaje se constituye como género autónomo en la modernidad a partir de los aportes, en principio, de los artistas románticos, que dejaron de considerarlo como un telón de fondo para trabajar en torno a él como unidad pictórica en sí. Alain Roger (Cf. 2007) considera que el paisaje se constituye en la modernidad como un espacio que reflexiona sobre las emociones subjetivas $\mathrm{y}$, a su vez, como un tópico privilegiado para la 
exploración de la realidad. A esto se agrega el hecho de que la incorporación de la tradición vinculada a la representación del paisaje permite al artista ingresar a una discusión local donde, desde el surgimiento de una academia artística, la pintura argentina se avocó a la discusión de la nación a través de dicho género (Cf. Malosetti 2007).

En este punto me interesa destacar que la referencia al paisaje, y particularmente a la tradición del paisaje urbano, instala el concepto de unidad pictórica, ausente y antagónica al modo de componer que el collage como principio compositivo plantea. Esta tensión en la composición da cuenta del aspecto transitivo de estas obras, puesto que en las obras posteriores que aquí estudiaremos esta cualidad tiende a desaparecer para priorizar la construcción que requiere el género paisaje.

Dr. L. M. Drago, con barreras averiadas contiene diversos procedimientos que aún involucran al collage como principio compositivo; este proceder lleva a la pintura a presentar figuraciones que no coinciden en su escala. Las fuentes fotográficas utilizadas en la elaboración de esta pintura (imágenes 2 y 3) develan el modo constructivo de la composición, la que articula en su planteo distintos elementos emblemáticos en relación con el espacio que se desea representar (la cabina de señales, las barreras, el cartel nomenclador de la estación). Se adhiere a esta composición el retrato del guardabarrera portando un banderín que indica detención. En este sentido, en esta obra las diferentes escalas de los diversos elementos junto a la superposición que estos manifiestan entre sí develan al espectador el carácter fragmentado de la composición. Este procedimiento se hace particularmente evidente en la superposición de uno de los extremos de la cabina de señales con la línea roja lateral que por su disposición reitera el marco de la pintura.

Otro aspecto importante para observar es la firma en lápiz del artista, la cual acompaña un transfer con la firma que Van Eyck signó el retrato del matrimonio Arnolfini ${ }^{8}$ (imagen 4). Esta relación entre la firma de Larrambebere y la firma de Van Eyck no es casual, sino que da cuenta de un posicionamiento del artista. Recordemos que la firma completa del artista flamenco en el cuadro mencionado rezaba "Jan Van Eyck estuvo presente", y de esta manera evidencia el lugar del artista como testigo y, por continuidad, de la pintura como registro histórico. La cita busca en tal sentido destacar la labor documental de la pintura como registro y, por otro lado, inscribir su trabajo dentro de la tradición de las bellas artes, y se opone así a la tendencia objetual y conceptual ${ }^{8}$ que signa la escena dominante del arte en Buenos Aires durante la década de los noventa (Cf. Fressoli, 2015). Por otra parte, la relación entre las dos signaturas condensa la presencia de dos sistemas: el transfer más automático, que casi no requiere intervención del artista, y el lápiz, que porta el gesto del trazo.

8 Estas tendencias se vinculan a una reorganización de la escena artística de Buenos Aires durante la década de los noventa, donde aparecen nuevos ámbitos de formación y circulación de las obras. La tendencia objetual se expresa mayormente en las producciones de un conjunto de artistas que confluían en la galería del rojas. Sus obras apelaban a la incorporación de materiales provenientes del mundo del consumo popular (baldes, peluches baratos, manteles de hule, cajas de jugos o jabones, entre muchos otros), que eran combinadas con procedimientos provenientes de las artes aplicadas. Algunos representantes de esta tendencia son Omar Schirilo, Marcelo Pombo y Feliciano Centurión. En relación con la tendencia conceptual, producciones como las de Jorge Macchi o Dino Bruzzone se valen de otro tipos de procedimientos, como fotografía, video o instalaciones (Cf. Pineau, 2012). 
En esta oposición entre un sistema que requiere gesto directo y otro que trabaja por imprimación (artesanal), el artista condensa dos formas de trabajo que se encuentran en repliegue, merced del avance de la cultura neoliberal. En tanto, esas formas de trabajo que el artista utiliza en su pintura, de algún modo, ponen en escena una subjetividad laboral que se denigra por aquellos años, subjetividad que por otro lado es también la que poco a poco comienza a deshabitar los paisajes representados ${ }^{9}$.

En Puente Alsina y Luis María Saavedra predominan aún restos del collage como principio. Sin embargo, en estas obras el procedimiento utilizado para componer cambia. Así es como la estructura de estas representaciones comienza a plantearse a partir de la proyección de fotografías (tomadas por el artista) sobre la superficie total del lienzo. A través de este procedimiento, comienzan a perder presencia aquellos elementos que en las representaciones anteriores constituían objetos o situaciones inventadas por el artista, a la vez que la composición se unifica y se acerca, en tal sentido, a la tradición del paisaje en la pintura. En estas obras la representación del espacio comienza a capturar aspectos indiciales provistos por el sistema fotográfico, a partir de los que se planteará la base de la composición. De este modo, en estos casos, es el nuevo procedimiento de proyección fotográfica el que instala el

9 Se trata de un cuerpo de trabajo vinculado al ferrocarril, ya que el proceso de privatización fue acompañado por una enorme cantidad de despidos y jubilaciones forzosas. Así mismo, este vaciamiento se extiende a otros sujetos que habitaban los espacios y que se retraen por los nuevos hábitos de consumo, junto al decrecimiento generalizado del mercado laboral. Es válido resaltar que por estos años, el artista se halla comprometido en sostener la técnica de impresión de boletos que estaba siendo abandonada y que corría riesgo, como muchos otros bienes por entonces, de perderse como chatarra. concepto de testigo, que en la representación de Drago se enunciaba por referencia a Van Eyck.

Por otro lado, en estas obras de tránsito comienzan a experimentarse variaciones en la paleta que desecha progresivamente el uso saturado del color, aspecto que distinguía la serie Marcas producidas con anterioridad por el artista. Finalmente, se combinan detalles en los que se observan zonas que parecen haber quedado sin trabajar; en estos el lienzo y el trazo previo del lápiz que planteó la estructura de la composición quedan a la vista.

Todas estas variables comienzan a instalar nuevas consideraciones en torno a la pérdida de una experiencia histórica, dado que todas ellas progresivamente comienzan a confluir en la producción de un extrañamiento del espacio cotidiano. De este modo, nos enfrentamos a un cambio en el sistema de representación que el artista produce, donde la reflexión pictórica comienza a desplazarse hacia una relación crítica con el sistema fotográfico.

\section{LA DESOLACIÓN DE LA PALABRA Y LA PRECARIEDAD COMO EXPERIENCIA DE LA PINTURA}

En este apartado propongo al lector el análisis de un conjunto de obras producidas por el artista en 1997, entre ellas están $L a$ Paternal (FCGSM) (imagen 7); Cnel Fco Lynch (FCGU) (imagen 8) y Dr. Antonio Sáe$n z$ (FCGB) (imagen 10). Estos trabajos se constituyen a partir del registro fotográfico de carteles nomencladores ${ }^{10}$ ubicados en

10 Nomenclador es el nombre que reciben los carteles que portan los nombres de la estaciones en el léxico ferroviario. 
diversas estaciones ferroviarias de Buenos Aires y alrededores. Aquí definitivamente se instala el procedimiento referido en el apartado anterior, el cual consiste en la proyección lumínica de un registro fotográfico, elaborado previamente por el artista, sobre la superficie total de un lienzo. A partir de esta operación el artista plantea el dibujo estructural de la composición. El resto de los elementos (como textura, color, volumen) será trabajado sin la proyección, utilizando la fotografía como guía. Estos aspectos serán por lo tanto sintetizados o inventados durante el trabajo del artista. Sobre las obras que están contenidas en esta selección, el artista comenta:

En el caso del paisaje me parece, que en el momento en el cual vos planteas una visión tan idiota (porque es tan poco interesante como paisaje, tan cotidiano y tan común) la pintura jerarquiza la imagen y genera preguntas. Entonces cuando uno como pintor pone el encuadre y el foco en un determinado paisaje, está lo justo y necesario para poder ver lo que está ahí. Si yo te pongo un personaje ahí no podes ver el énfasis en la ausencia, en lo que tiene que ver con la pintura. En el detalle de cómo está pintada. (Larrambebere, mayo de 2013 mayo. Comunicación personal)

El pintor que encuadra y enfoca un paisaje ordinario, pero que se resiste a abandonar el pincel en la realización de una operación que, ya desde la enunciación, es referida como fotográfica. Es decir que la fotografía como elemento que se articula en la reflexión pictórica no se restringe a la proyección fotográfica sobre el lienzo sino que, como se declara en las palabras del artista y en los procedimientos, adquiere también presencia en los modos de pintar.

Como mencioné en el apartado anterior, a partir del nuevo procedimiento implementado en el trabajo del artista, en estas obras las representaciones pictóricas advienen huella de la fotografía. No solo porque la fotografía es fuente, sino porque la pintura emula en sus modos de trabajo una modalidad fotográfica: el lienzo adviene a través de la mano del artista la superficie sensible que captura los elementos estructurales de la fotografía proyectada. La obra produce así una tensión entre dos sistemas: el sintético, que refiere a la pintura, y el analógico, que refiere a la fotografía. Tomo esta distinción de Pierre Sorlin, quien considera que la imagen sintética se comprende como una reproducción no exacta, sino coherente de la realidad, que se enfoca no en un hecho determinado sino en una idea. En tal sentido, sostiene que la imagen sintética presenta un resumen ideal, acumula atributos del objeto representado y destaca en su trabajo aspectos que resumen o contienen un proceso. Mientras el sistema de la imagen analógica difiere el modo como la realidad se captura. Es decir, aquí el sistema óptico regula la figuración fotográfica $\mathrm{y}$, a través de él, explora aspectos que el ojo humano no percibe. Finalmente, Sorlin agrega que la imagen analógica, a diferencia de la sintética, corresponde a un fragmento del mundo del cual es huella. Es analógica porque proporciona identidad en la relación entre los diversos elementos del mundo y su representación (Cf. Sorlin, 2004).

En el procedimiento que el artista desarrolla en la producción de los paisajes incluidos en este apartado, la pintura adviene huella y 
en ese acto incorpora un aspecto sustancial del sistema analógico desde el que se constituye. En este proceder la pintura instala la referencia de un espacio familiar, el cual será sometido a diversas operaciones pictóricas tendientes a realizar transformaciones sobre el concepto de espacio que las fotos tomadas como referencia registran. Estas transformaciones sobre el concepto de espacio operan en detrimento del tiempo de la imagen. En este marco, se comprende la recuperación de cierta poética metafísica que sedimenta estas composiciones. La captura del instante fotográfico es mediante las operaciones del sistema sintético extraído del tiempo y la historia se trama así en la pintura como problema de espacio extrañado.

En la relación particular entre lo sintético y lo analógico, que la modalidad de estas pinturas plantea, los elementos de identificación que provienen del sistema analógico son reducidos a su mínima expresión. El resto analógico persiste en estos trabajos a través de la organización interna de los distintos elementos que componen la representación pictórica. Mediante el uso de la proyección, en forma de diapositiva, opera el dispositivo óptico de la foto en el lienzo. En esta operación ingresan a la pintura elementos que aportan a la mediación de la cámara fotográfica. La fotografía, a la vez, permite el ingreso de lo que el ojo no ve en la representación y evita la jerarquización de los diversos elementos que constituyen el campo visual ${ }^{11}$. Por todo esto, la

11 El campo visual que produce la mirada humana supone siempre la jerarquización de determinados elemento en detrimento de otros, los más cercanos al centro de la mirada más definidos y los periféricos con menor nitidez. El ojo de la cámara, en cambio, puede evitar esa jerarquización. Por ello a veces descubrimos en la fotografía elementos sobre los que inicialmente no nos habiamos interesado en la realización de la captura visual. identificación propia de lo analógico que permanece activa en la pintura se reduce al orden compositivo, es decir a una relación de proporción de los elementos que hacen a la captura fotográfica de un paisaje ordinario. Así lo analógico de la pintura permanece en estas representaciones en la estructura de su composición.

Así mismo, estas composiciones pictóricas exhiben en su producción el uso de estrategias capturadas del sistema fotográfico, imitando lo que en fotografía se denomina profundidad de campo. En la pintura se observa que todos los puntos de la representación comparten un alto grado de nitidez que anula la idea de distancia. El término profundidad de campo refiere al espacio por delante y por detrás del plano enfocado, el cual se conforma entre el primero y el último punto aceptablemente nítido reproducidos en el mismo plano de enfoque. En todos los casos este procedimiento, que en la fotografía es posible merced de la apertura del diafragma, en las pinturas del artista se extrema a partir del tratamiento que se otorga a la luz. De este modo, se observa un uso extendido de una luz plana y sombras netas en el tratamiento pictórico que se expande a toda la superficie pictórica, y se crea así una sensación de nitidez homogénea. Se trata, de este modo, de una luz sintética que opera por contrastes fuertes; este procedimiento permite omitir los accidentes y, en tal sentido, expulsa los rastros de acción del pintor. Así es como se comienza a instalar un concepto de planeidad que será reforzado por otros aspectos de la representación.

En esta dirección, es posible mencionar la reducción progresiva que observa el espacio del andén representado en las pinturas; 
este es el indicio fundamental de la distancia desde la que el pintor trabaja. Mientras en La Paternal aún ocupa una franja importante de la superficie, en Cnel Lynch se reduce a la introducción de un pequeño plano inclinado y finalmente en Dr. Antonio Saenz se reduce a una línea negra paralela al marco inferior del cuadro. En esa operación se anula progresivamente la distancia de la mirada que observa y, a su vez, se reduce el ya de por sí restringido espacio de la representación, y de esta manera aporta al concepto de planeidad anteriormente mencionado.

Como aspectos generales de estas obras, es de interés destacar el color que se de-satura y adquiere valores altos; el contraste entre luz y sombra que borra los detalles, homogeneiza y abstrae a los elementos fundamentales de la composición; a lo que se agrega el repliegue definitivo de la figuración humana. Todos estos parámetros vinculan las búsquedas de esta serie a inquietudes de la pintura metafísica mediante las que se pretende dar cuenta de los fundamentos que constituyen el espacio registrado por el artista. Por esta razón, a diferencia de otras representaciones del artista no incluidas en este artículo ${ }^{12}$, en este caso los paisajes representados omiten toda marca de acción. Por ello, en el desplazamiento de la fotografía a la pintura, los elementos que se vinculan a lo contingente del espacio, como el caso de las marcas de grafitis que se observan en la fotografía de Coronel Lynch (imagen 9), son borrados en la pintura. La

12 Me refiero a la serie Marcas, donde el artista se ve abocaba a registras una serie de iconos comerciales que debido a la crisis de la industria nacional o los cambios en las prácticas y consumo culturales comenzaban a desaparecer. En esta serie mediante los motivos y procedimiento el artista destacaba los diversos usos y experiencias vinculados a diferentes marcas comerciales, tcomo fluido Manchester, Pelotas Pulpo, Goma dos Banderas, entre otros. búsqueda de los fundamentos lleva a borrar los usos y funciones del espacio; por esa operación un territorio familiar y ordinario resulta extraño.

Como parte de este proceder, la figura humana se sustrae de la composición, debido a que su presencia instala procesos de identificación contrarios a la intención de la pintura, que parecen converger hacia la desolación de la palabra en el espacio. Al no haber figuración humana, la letra se independiza del uso: se convierte en no familiar. Por ello, en este sistema de representación la función literaria de las palabras representadas destacan la ausencia ${ }^{13}$, por cuanto hacen referencia a un espacio de vivencia común en un entorno donde las marcas de acción se han suprimido. Todos los indicios de usos son aquí obliterados, el tiempo aparece así detenido a partir de borrar los elementos contingentes de la representación. De este modo, la supresión progresiva de la distancia en la visión del espacio y la instauración de lo plano manifiesta una tendencia a negar el espacio donde el sujeto observador se inscribe en la pintura a partir de un punto de vista ideal. La tendencia a lo plano suprime la perspectiva y en ese acto al sujeto que forma es constituyente de esa mirada.

El carácter geométrico de la composición y lo plano dan sensación de espacio intransitable y abstracto; esta estrategia lo retira del tiempo, así el espacio representado adviene inaccesible, no habitable. Mediante este efecto el recuerdo del espacio se instala aquí a través de la tragedia de su imposible

13 Al decir de Eagleton, lo literario es un término más funcional que ontológico. Se refiere a lo que la palabra hace y no al ser fijo de las cosas, sino al papel que desempeña el texto con su entorno (Eagleton, 2007). 
recuperación y vivencia, las operaciones que lo reinstalan lo vuelven distante, como augurio de una tragedia inminente.

Luego de esta serie de paisajes ferroviarios, el artista amplía su búsqueda a la incorporación de arquitecturas fabriles, en general edificios paradigmáticos de la industria nacional argentina; así como también otras representaciones de espacios urbanos de uso colectivo, característico de prácticas que, al igual que sucede con la industria, entran en progresivo deterioro hacia fines de la década de los noventa. Entre estos se encuentran los clubes sociales y deportivos, cines, así como las fachadas de instituciones emblemáticas de la memoria colectiva, como Radio Colonia. Este último fue un caso emblemático de la relación Argentina-Uruguay en tiempos de la dictadura a través de la voz de Ariel Delgado, un correntino que transmitía más noticias que las que se podían escuchar aquí. En este sentido, sus modelos funcionan como registro de la memoria colectiva.

Entre 1999 y 2002 el concepto de extrañamiento de un espacio vinculado a la historia colectiva adquirirá nuevas modalidades que harán más contundente el proceso de desolación y ausencia que inician las pinturas producidas a partir de 1997. En este conjunto de obras, donde el procedimiento compositivo se mantiene, veremos que se modifica la relación entre lo sintético y analógico a favor del primero. Es decir, si bien los elementos compositivos que persisten operan como restos analógicos, estos se reducen aún más eliminando, en estas representaciones, la presencia de los detalles en la descripción del espacio. El modo de pintar observa una síntesis mayor, que descarta ya radicalmente la presencia de texturas y disminuye la carga matérica, al mismo tiempo que se modifica la estructura del soporte. En estos trabajos veremos que se articulan la austeridad de los cuadros de Suárez con la precariedad de las composiciones de Diomede consignadas al inicio de este artículo. El proceso de austeridad que se advierte en el modo de pintar que se observa particularmente en diversas obras realizadas hacia 1999, como Cine Libertad (Conchillas ROU) (imagen12); Galería Coghlan (imagen 14) y Fábrica de pelotas Pulpo en Saavedra (imagen 13). Así Cine Libertad presenta el tratamiento plano del color, Galería Coghlan deja a la vista como fondo del paisaje el lino que constituye el soporte, el cual solo es trabajado con una base transparente; aspecto que se intensifica en el caso de Fábrica de pelotas Pulpo, donde el soporte se desplaza al cartón adviniendo una materialidad más endeble que es expuesto como tal sin preparado.

Al proceso de ausencia y desolación que se advertía en la obras de 1997, estos trabajos agregan el concepto de deterioro y precariedad de los diversos espacios que sedimentan un pasado colectivo. En este caso la consideración se instala a través de los modos de pintar y del cambio de las superficies pictóricas que extreman la síntesis de las representaciones anteriores y encarnan la austeridad a partir de la factura y materialidad de la pintura que se reduce. Finalmente, es común a este conjunto de obras un punto de vista bajo, y en general inclinado. La pérdida de frontalidad, que se observaba en las obras de 1997 parece en esos casos instalar una idea de infancia o tránsito de quien observa un espacio común perdido. Así, ambos aspectos instalan la consideración de un tiempo distante. 
El proceso de avance de lo sintético sobre lo analógico llegará a su punto radical en diversas obras que integran la instalación Buenos Aires y sus alrededores realizada en 2002 en la Galería Klem. Estas pinturas mantendrán, en líneas generales, los motivos anteriores y los puntos de vista bajos, a la vez que las dimensiones de sus lienzos se reducen drásticamente ${ }^{14}$. En estos casos, la superficie del soporte se evidencia no ya como fondo sino como rastro del trabajo, las marcas de las cintas de papel utilizadas por el pintor permanecen en la representación, desplazando el concepto de deterioro y descuido al trabajo (imágenes 15 y 16]) Por otro lado, en el caso de Villa Ortuzar (imagen 17), observamos que la síntesis avanza hasta tal punto extremo que la puerta de la fábrica textil (muy reconocida dentro de la industria nacional argentina) adviene casi monocroma y geométrica, y la expansión difusa del blanco en la superficie instala la idea de borramiento o pronta extinción.

\section{El RECUERdo COMO ASUNTO de LA PINTURA DE HISTORIA}

Rancière sostiene que en el régimen representativo la profundidad óptica estuvo ligada al privilegio de la historia. En ese marco, la pintura, a través de esta cualidad podía captar la palabra viva en acto, el momento decisivo de una acción y una significación. En ese sistema la palabra adviene normativa en relación con los elementos que la representación ordena ${ }^{15}$. Pero dentro del régimen estético los modos como el traba-

14 De acuerdo con el artista, este aspecto refiere a una condición de la producción dada por el contexto de crisis que impulsaba a reciclar los lienzos que se tenía.

15 El sistema refiere a lo que Erwin Panofsky buscó ordenar a través del método iconológico e iconográfico, donde el uso de la literatura para jo artístico conceptualiza la historia varían drásticamente y la relación entre lo literario y lo visible se transforma. Dentro de este régimen las producciones artísticas se desarrollan con relación a una nueva interfase que revoca el orden representativo (Cf. Rancière, 2011). En tal sentido, Rancière afirma:

Es entonces sobre lo plano de la página, en el cambio de la función de las 'imágenes' de la literatura o el cambio del discurso sobre el cuadro, pero también en los trazos de la tipografía, del afiche y de las artes decorativas, que se prepara en gran parte la 'revolución anti-representativa' de la pintura. Esta pintura, tan mal denominada abstracta y supuestamente devuelta a un médium propio, forma parte de una visión de conjunto de un nuevo hombre alojado en nuevos edificios, rodeado de objetos diferentes. Su planicie está ligada a la de la página, del afiche o de la tapicería. Esta es la interfase. Y su pureza anti- representativa se inscribe en un entrelazamiento del arte puro y el arte aplicado, que le da de entrada una significación política. (2009, p. 15)

En este régimen se inscribe la obra de Larrambebere, que articula de modo singular la experiencia de su contemporaneidad, signada por un drástico retiro de lo público, las prácticas colectivas del espacio social y la crisis y deterioro de materialidades históricas vinculadas al desarrollo del Estado benefactor. Por ello, en las obras aquí estudiadas, la historia no se trama como asunto descriptivo, sino en los modos que adquieren los materiales que su representación

la comprensión en la pintura recupera un condición de producción histórica en la obras renacentistas (Didi-Huberman, 2010). 
articula. Es decir, la historia no se vincula en las representaciones del artista a la reposición de acontecimientos ejemplares o significativos de un determinado tiempo, sino al trabajo con cualidades que capturan particularidades de su tiempo.

De este modo, las variaciones sobre la función de lo literario, junto a las modalidades de trabajo que sus procedimientos incorporan, traman una experiencia particular sobre la que la pintura del artista reflexiona y acciona. Esto es, la extensión y detención del instante fotográfico merced del sistema pictórico (a través de la tensión analógico-sintético), así como la progresiva síntesis y precariedad que observa el modo de pintar. Todos estos aspectos comienzan a evidenciar un modo singular en el cual en la pintura del artista se figura la historia. La incorporación en el lienzo del instante fotográfico junto al inevitable desgaste y crisis del espacio común parecen tensionarse con una voluntad de retención que se expresa en la intención de suspender el tiempo cuando la acepción que este adquiere en la cultura adviene cada vez más corrosiva al pasado que se busca rescatar o visibilizar. Dicho pasado se encarna en la elección de motivos espaciales, gráficos y objetuales que refieren a lo colectivo: en el uso común del espacio público, en el desarrollo de la industria nacional argentina, en los espacios de ocio vinculados a prácticas de sociabilidad colectiva.

En este sentido, sostengo que las obras del artista se inscriben dentro del realismo y la pintura de historia, dialogando con las tradiciones locales que se abocaron a la discusión de la nación. Por ello, la vuelta al paisaje industrial y urbano, que había estado en los temas que iniciaron la tradición de la pintura nacional argentina, confiere un tópico que reactualiza o inscribe el trabajo del artista en la discusión sobre la nación en la pintura (Cf. Schuster, 2013). Es posible hablar de realismo por cuanto las representaciones aquí estudiadas buscan recuperar aspectos objetivos de un acontecer contemporáneo y porque a través de la mirada se incorporan aspectos drásticos que hacen a la transformación del espacio. El obrar del artista captura así restos de un proceso contemporáneo.

La relación que estos trabajos establecen con lo histórico es compleja, puesto que estas pinturas recuperan y reflexionan sobre la crisis de la historia como suceso singular del tiempo en el que estas obras son producidas. Dicha crisis se encarna en la conceptualización pictórica del espacio y en la elaboración de tensiones entre la visibilización de un espacio en crisis y la intención de su retención.

De este modo, el recorrido realizado por la obra de Larrambebere da cuenta de constantes variaciones en torno al concepto de espacio en la representación pictórica. Por ello, los diferentes momentos presentados en su obrar cualifican el espacio como espacio perdido, espacio destemporalizado y espacio degradado. La pérdida, ausencia y precariedad intentan capturar elementos propios de su tiempo; dan cuenta de un proceso crítico que advierte la configuración de un espacio particular, aquel que posee sedimentaciones que lo vinculan a condiciones del Estado de Bienestar.

Otra constante se trama en las relaciones que los diferentes trabajos advierten entre lo singular del recuerdo, que en la obra 
refiere a los afectos y vivencias del artista, y una experiencia colectiva que se trama en los motivos de las representaciones.

Ambos aspectos configuran una modalidad crítica del recuerdo que se trama como recuperación y visibilización de lo histórico en el espacio (aun cuando lo histórico se evidencia por la ausencia de tiempo). En este proceder, el recuerdo adviene crítico a su contemporaneidad en cuanto se constituye a partir de una economía de tiempos, alterna a los modos dominantes que plantea el régimen temporal de la cultura neoliberal, donde la valoración extrema del presente sobre el pasado y el futuro confluyen en un progresivo desprestigio de lo histórico y consiguiente crisis de la experiencia histórica, lo que a su vez niega a los sujetos su capacidad de acción en el mundo.

\section{REFERENCIAS}

AAVV (2008). Pablo Suárez. Buenos Aires: Centro Cultural Recoleta.

AAVV (1999). Cantos paralelos: la parodia plástica en el arte argentino contemporáneo. Buenos Aires: Fondo Nacional de las Artes.

Benedit, L. (Ed). (1999). Artistas argentinos de los '90. Buenos Aires: Fondo Nacional de las Artes.

Didi-Huberman, G. (2010) Ante la imagen. Preguntas formuladas a los fines de una historia del arte. Murcia: Centro de Documentación y Estudios Avanzados de Arte Contemporáneo [Cendeac].

Eagleton, T. (2007). Una introducción a la teoría literaria. México, D.F.: Fondo de Cultura Económica.

Fressoli, G. (2015). El obrar del arte en la producción de modos críticos del recuerdo. Los artistas de lo colectivo hacia mediados de los años 90. Revista Telar, (13-14), 358-377.

Fressoli, M. y Diez Fischer, A. (2013). El collage en el trabajo de Patricio Larrambebere. Variaciones a partir de la muestra ferro-carriles argentinos en el Museo Nacional Ferroviario. XIV Jornadas Interescuelas/Departamentos de Historia. Universidad Nacional de Cuyo, Mendoza, Argentina.

Gibson, J. (1974). La Percepción del mundo visual. Buenos Aires: Emecé.

Malosetti Costa, L. (2007). Pampa, ciudad y suburbio. Buenos Aires: Fundación Osde.

Massuch, G. (2014). El robo de Buenos Aires. Buenos Aires: Sudamericana.

Rancière, J. (2009). El reparto de lo sensible. Santiago de Chile: LOM.

Rancière, J. (2011). El destino de las Imágenes. Pontevedra: Politopías.

Roger, A. (2007). Breve tratado del paisaje. Madrid: Biblioteca Nueva.

Schuster, G. (21 de noviembre de 2013). Las cualidades de figuración de la nación en el sistema de producción de las obras visuales. 3ras. Jornadas de Investigadores en Formación, Buenos Aires.

Pineau, N. (2012). Espacios de exhibición durante los años noventa en Buenos Aires y la formación de una nueva escena artística. En I. Balddasarre y S. Dolinko (Ed.), Travesías de la Imagen. Buenos Aires: Eduntref.

Sorlin, P. (2004). El 'siglo' de la imagen analógica. Los hijos de Nadar. Buenos Aires: La Marca Editora.

Svampa, M. (2005). La sociedad excluyente. La argentina bajo el signo del neoliberalismo. Buenos Aires: Taurus.

Virno, P. (2003). El recuerdo del presente, Buenos Aires: Paidos. 
Wartofsky, M. (1980). Visual acenarios: the role of representation in visual perception. En The perception of pictures. New York: Academic Press.
White, H. (2002). El contenido de la forma. Discurso narrativo y representación histórica. Buenos Aires: Paidós.

Wilson, S. (1975). El arte pop. Barcelona: Editorial Labor.

\section{REFERENCIAS DE LAS IMÁGENES}

Imagen 1. Patricio Larrambebere (1996),

Dr. L. M. Drago, con barreras averiadas.

Acrílico sobre tela $180 \times 100 \mathrm{~cm}$.

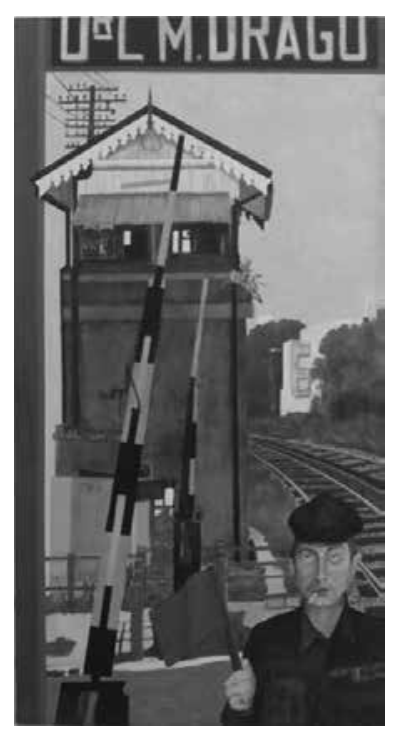

Imagen 2. Foto de la cabina de señales de la Estación Drago, tomada por el artista y utilizada en la composición de la obra Dr. L. M. Drago, con barreras averiadas.

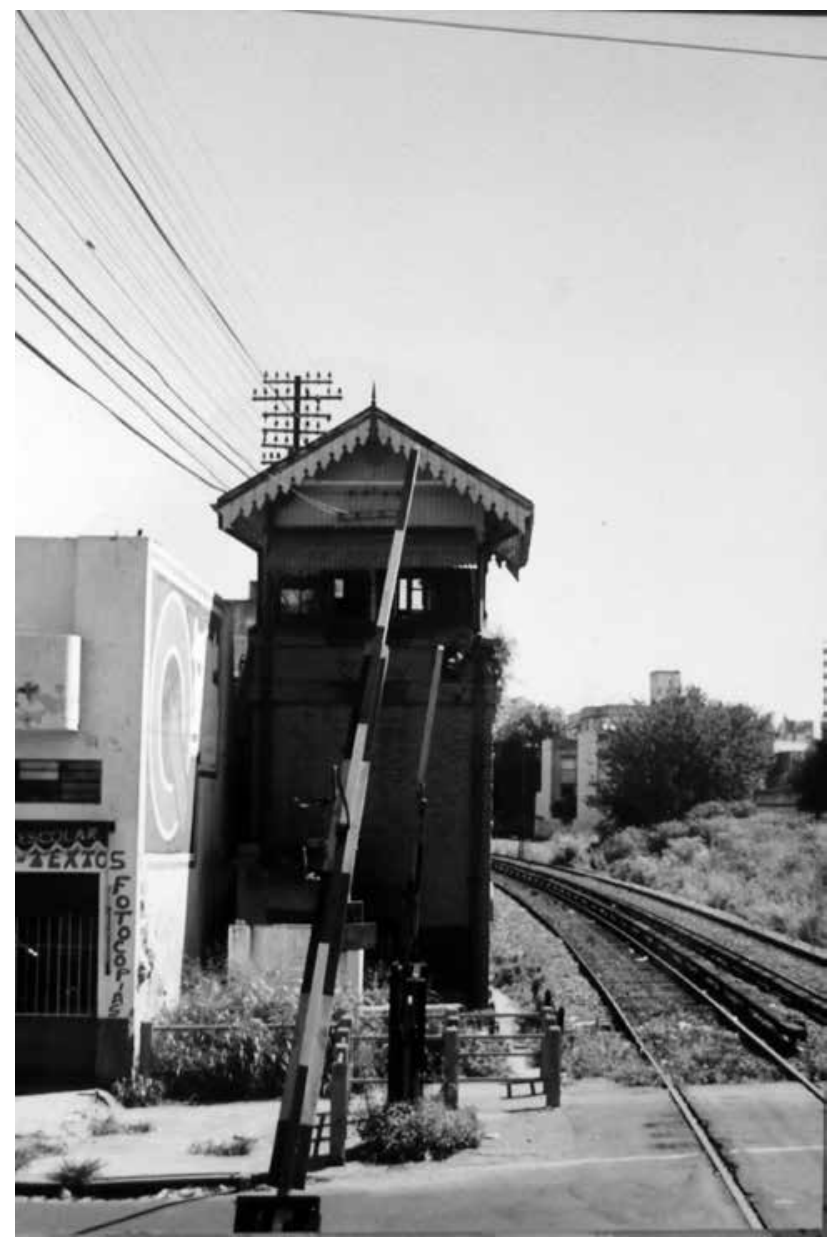


Imagen 3. Foto tomada por el artista en la Estación Drago y utilizada en la composición de la obra Dr. L. M. Drago, con barreras averiadas

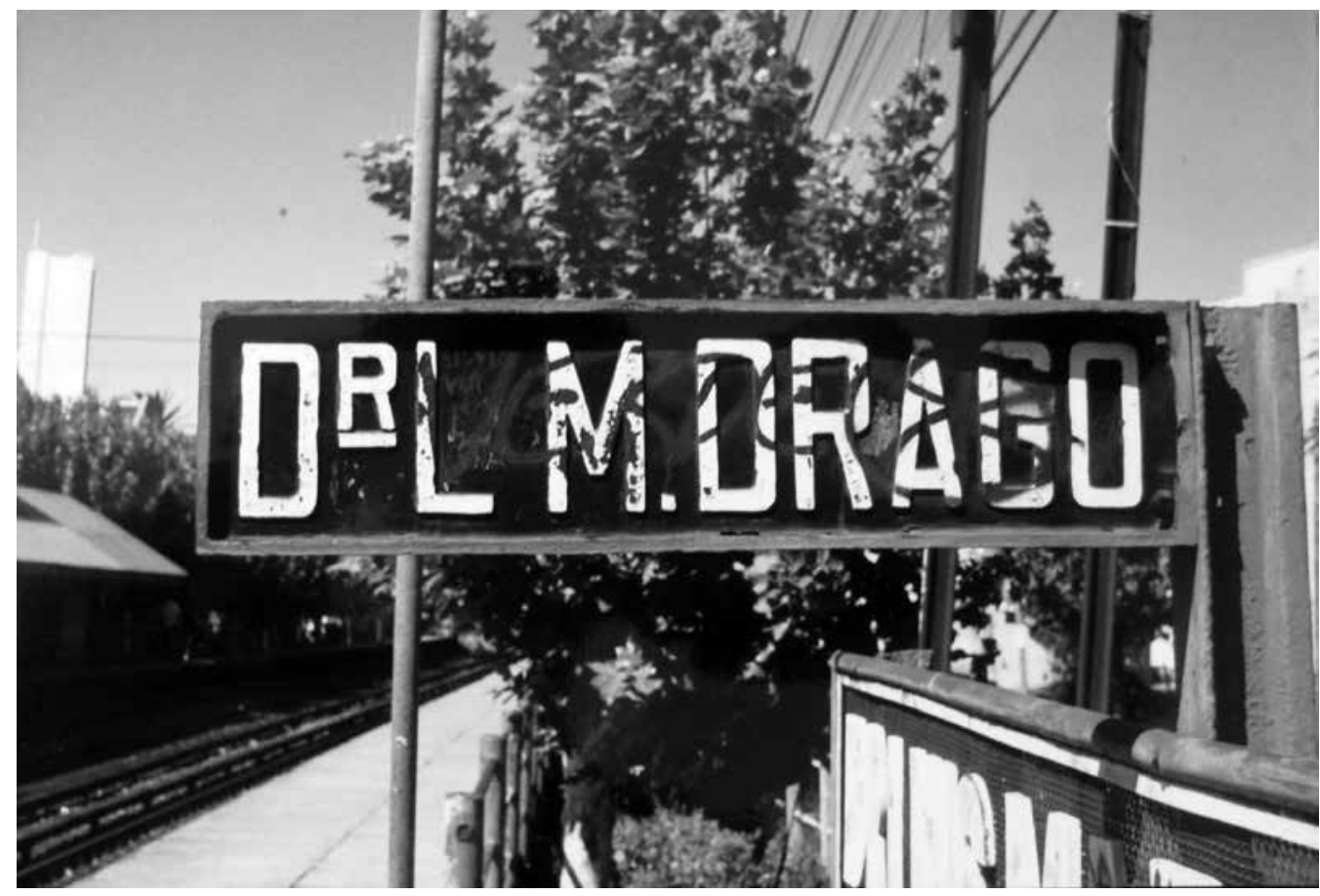

Imagen 4. Patricio Larrambebere. Dr. L. M. Drago, con barreras averiadas. Detalle de la firma del artista.

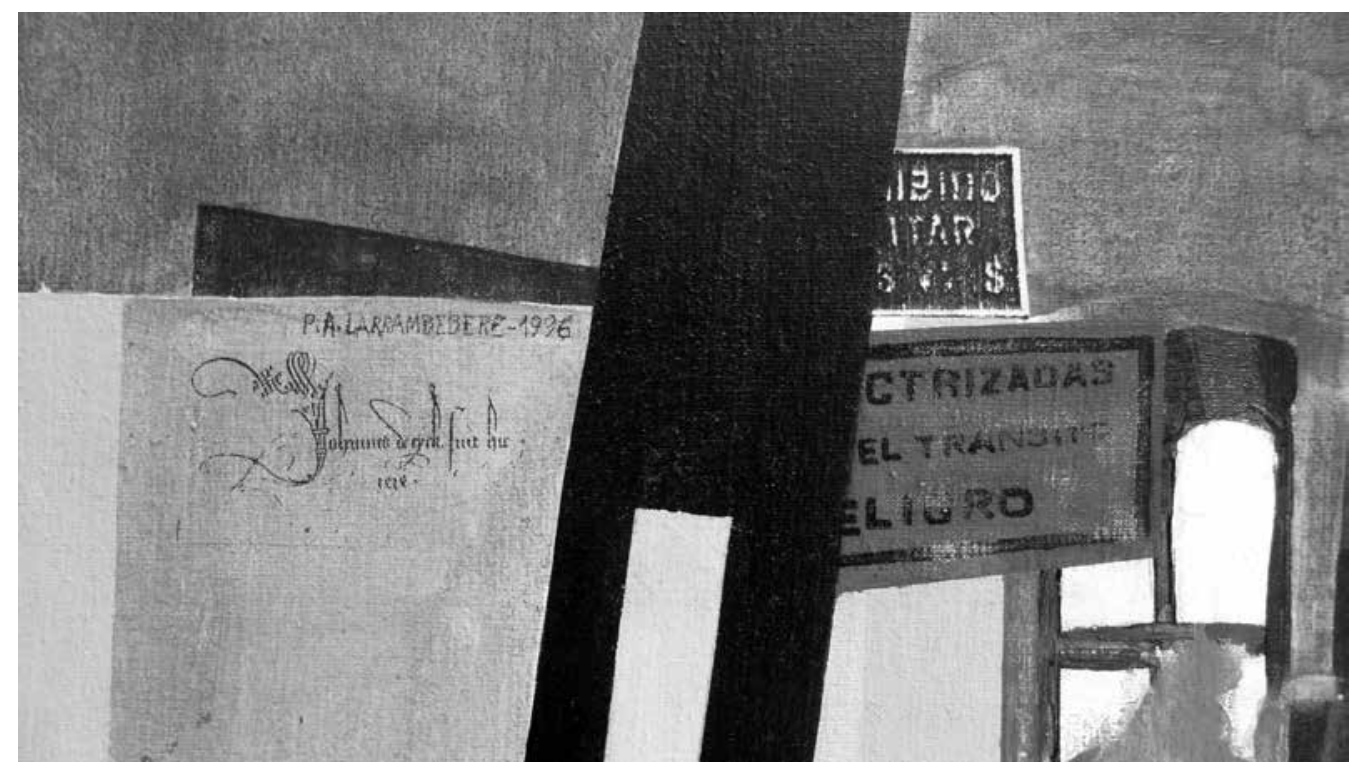


Imagen 5. Patricio Larrambebere (1996). Luis María Saavedra. Acrílico sobre tela $120 \times 100 \mathrm{~cm}$.

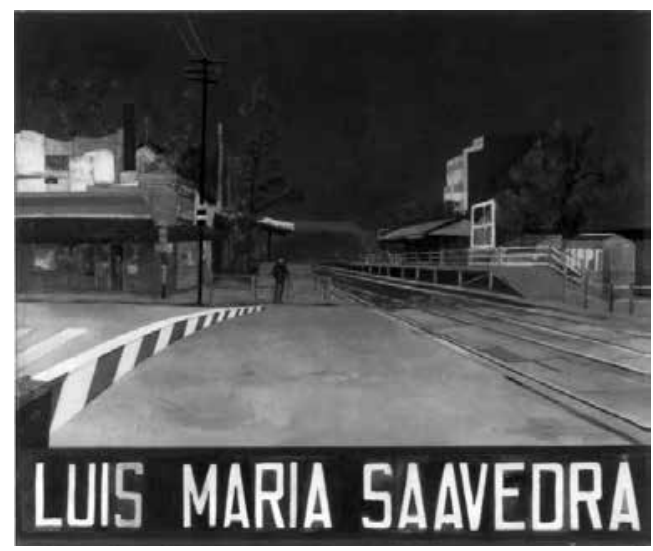

Imagen 6. Patricio Larrambebere (1998). Puente Alsina. Acrílico sobre tela $150 \times 90 \mathrm{~cm}$.

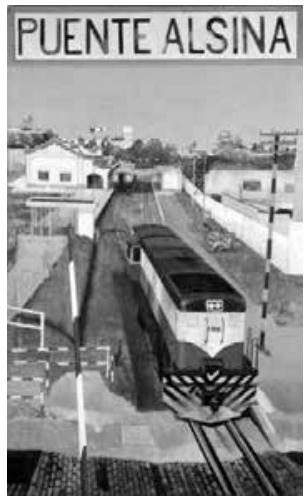

Imagen 7. Patricio Larrambebere (1997). La Paternal (FCGSM). Acrílico sobre tela $130 \times 110 \mathrm{~cm}$.

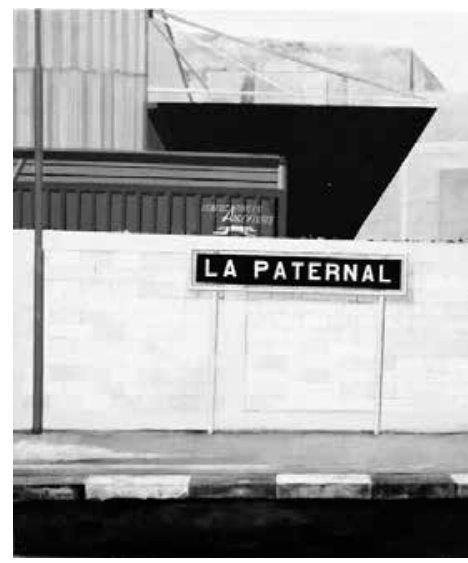

Imagen 8. Patricio Larrambebere (1997). Cnel. Fco. Lynch (FCGU). Acrílico sobre tela $150 \times 100 \mathrm{~cm}$.

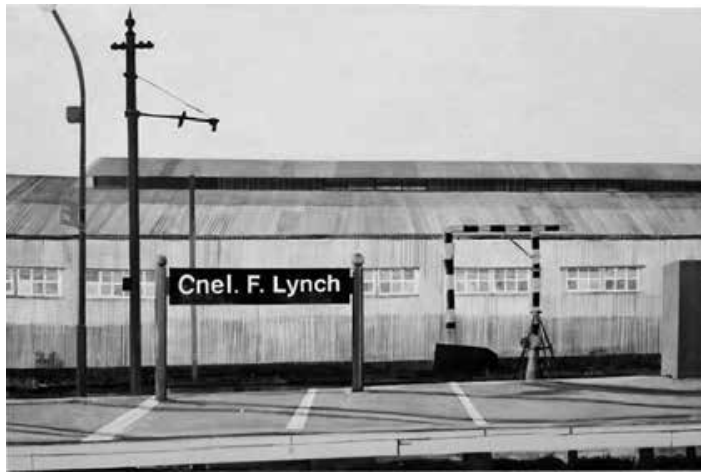


Imagen 9. Toma fotográfica del artista utilizada como proyección y referencia en la pintura Cnel Lynch. La cinta de papel indica el modo como el artista realiza recortes en el interior de la imagen a fin de componer la pintura

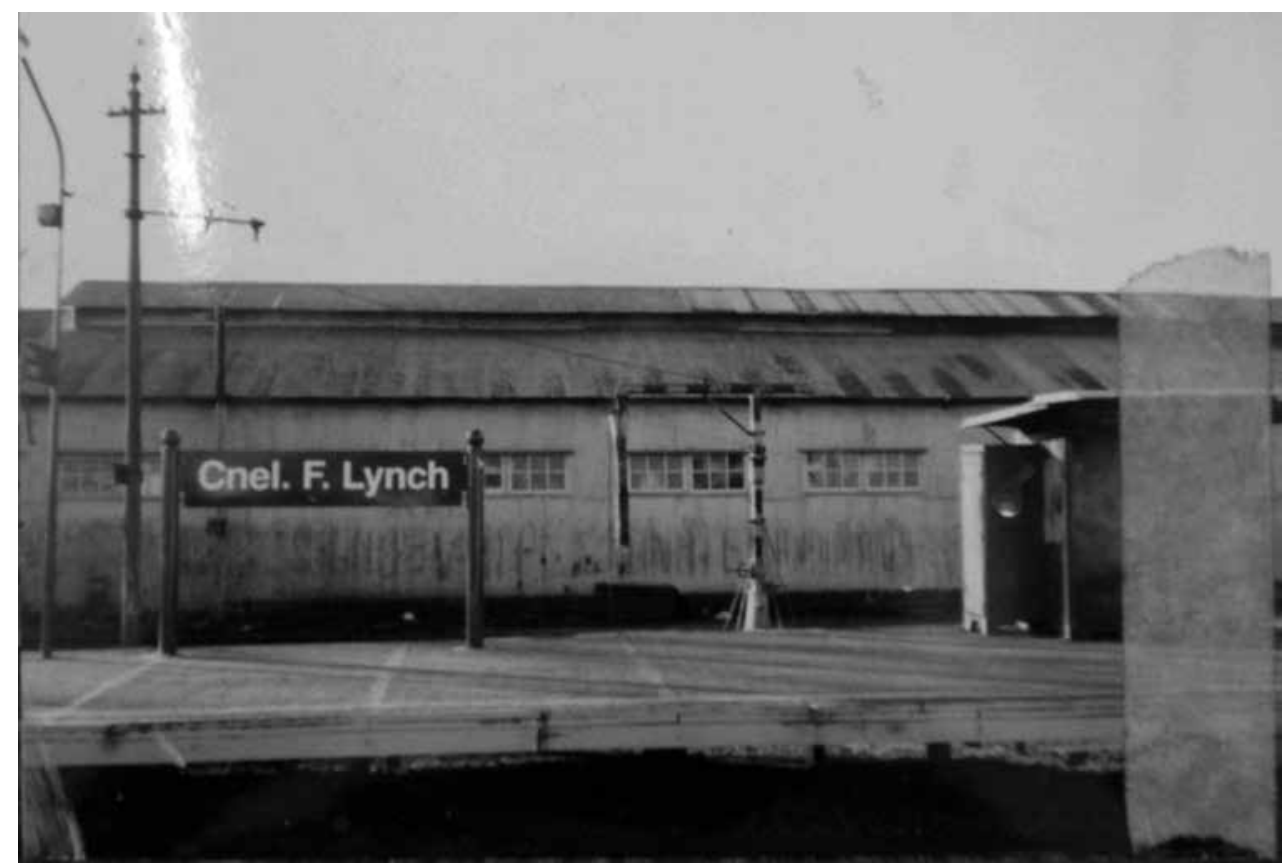

Imagen 10. Patricio Larrambebere, Dr. Antonio A. Sáenz (FCGB).

Acrílico sobre tela $150 \times 100 \mathrm{~cm} .1997$

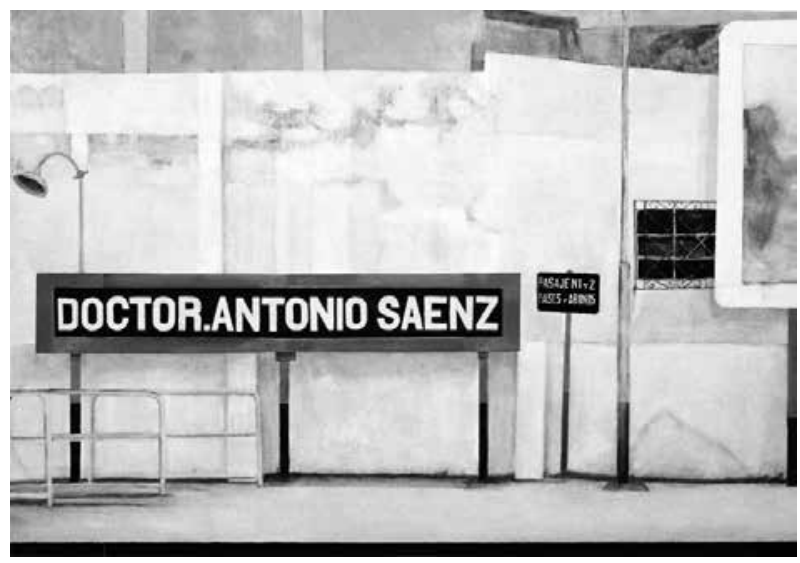


Imagen 11. Toma fotográfica del artista utilizada como proyección y referencia en la pintura Dr. Antonio A. Sáenz (FCGB).

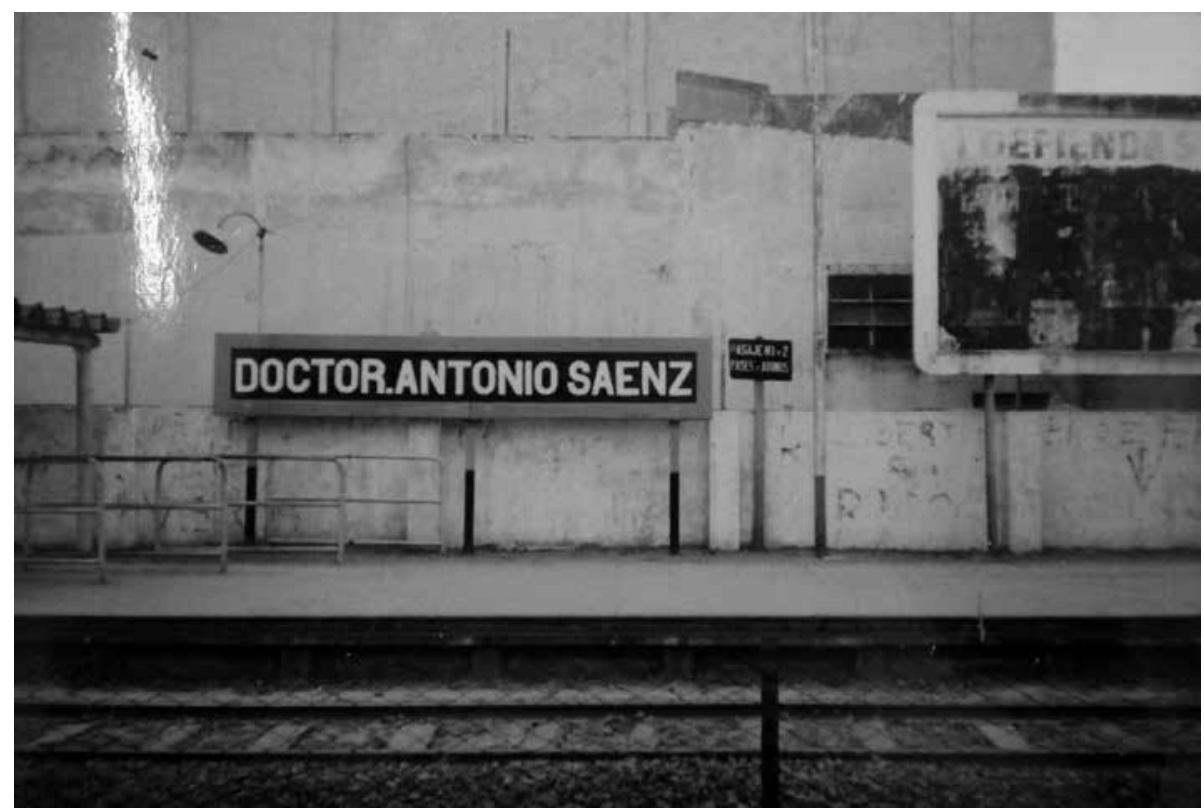

Imagen 12. Patricio Larrambebere (1999). Cine Libertad (Conchillas ROU). Acrílico sobre tela. $130 \times 110 \mathrm{~cm}$.

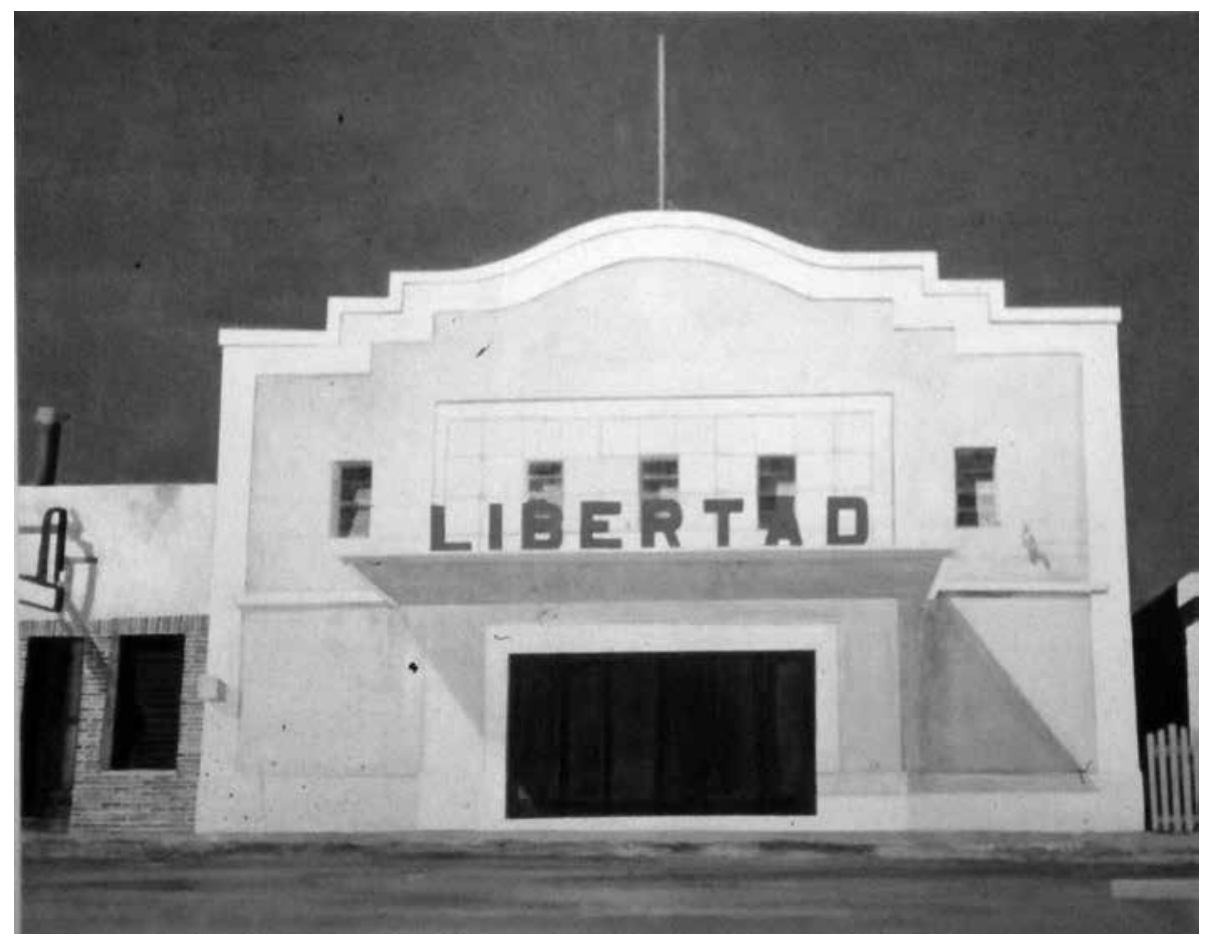


Imagen 13. Patricio Larrambebere (1999). Galería

Coghlan. Acrílico sobre lino. $160 \times 100 \mathrm{~cm}$.

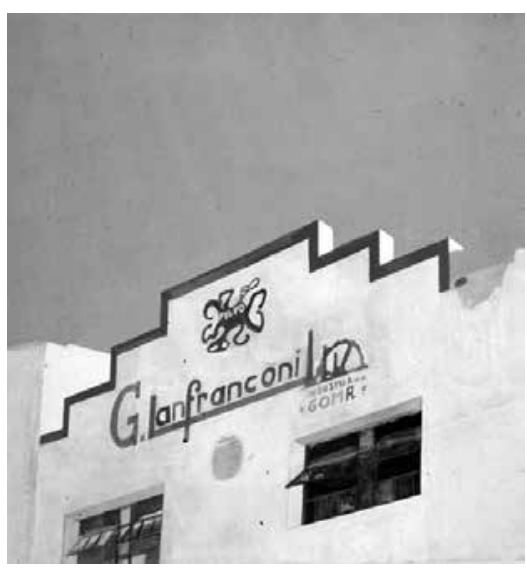

Imagen 14. Patricio Larrambebere (1999). Fábrica de pelotas Pulpo en Saavedra. Acrílico y lápiz copiador sobre cartón, 90 x $90 \mathrm{~cm}$.

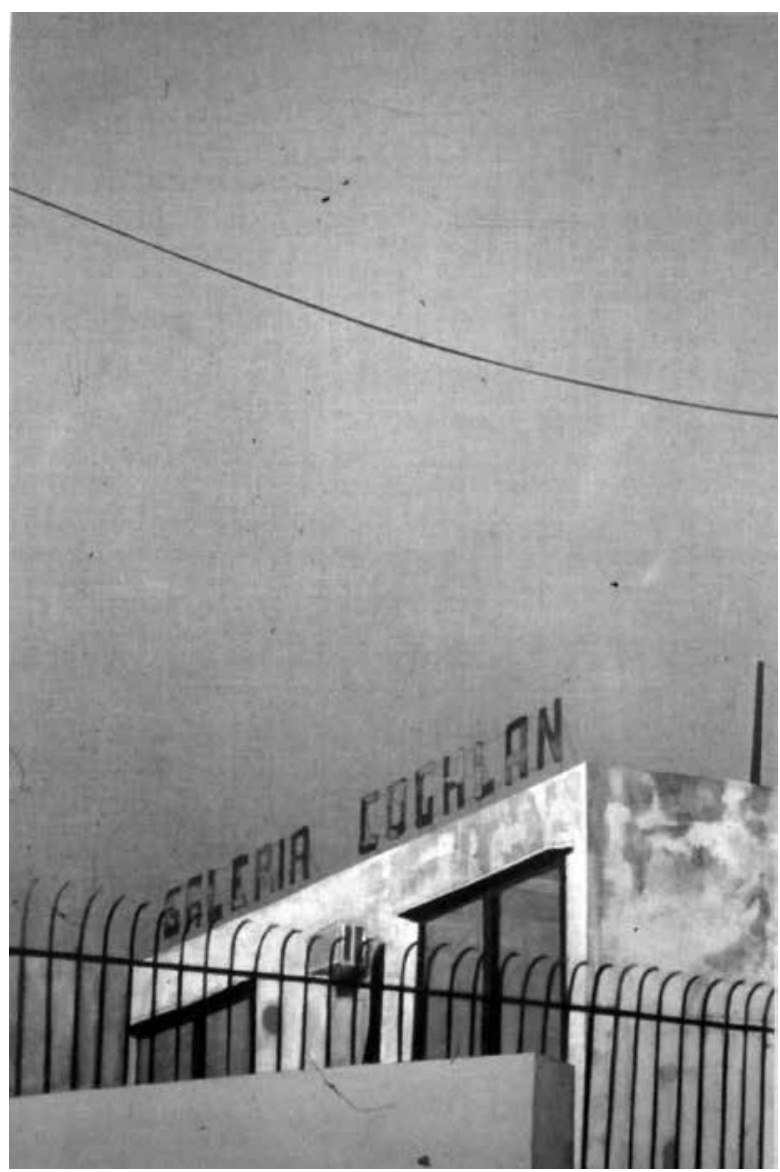


Imagen 15. Patricio Larrambebere (2002). Valentín Alsina. Acrílico sobre tela.

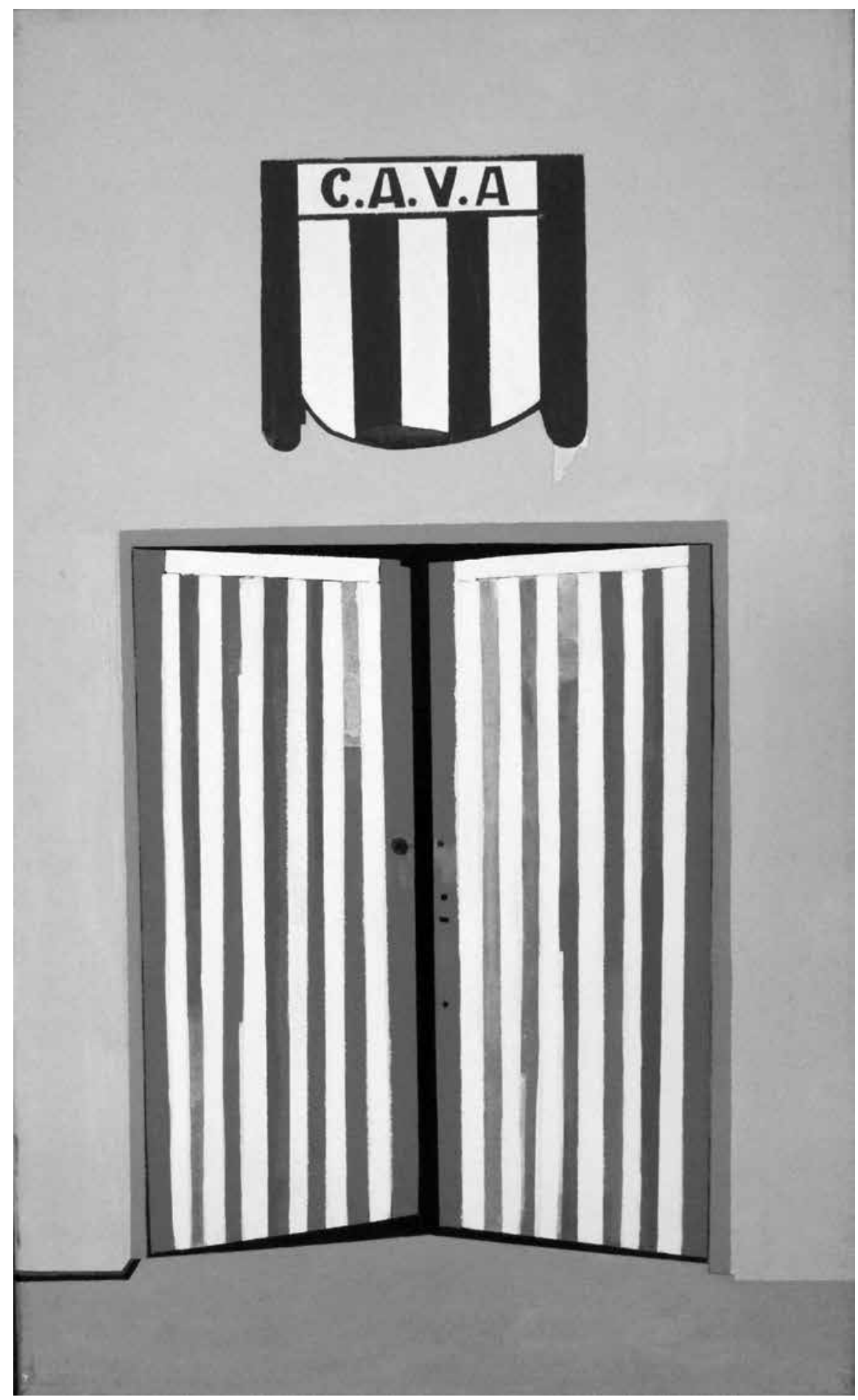


Imagen 16. Patricio Larrambebere. Valentín Alsina (detalle).

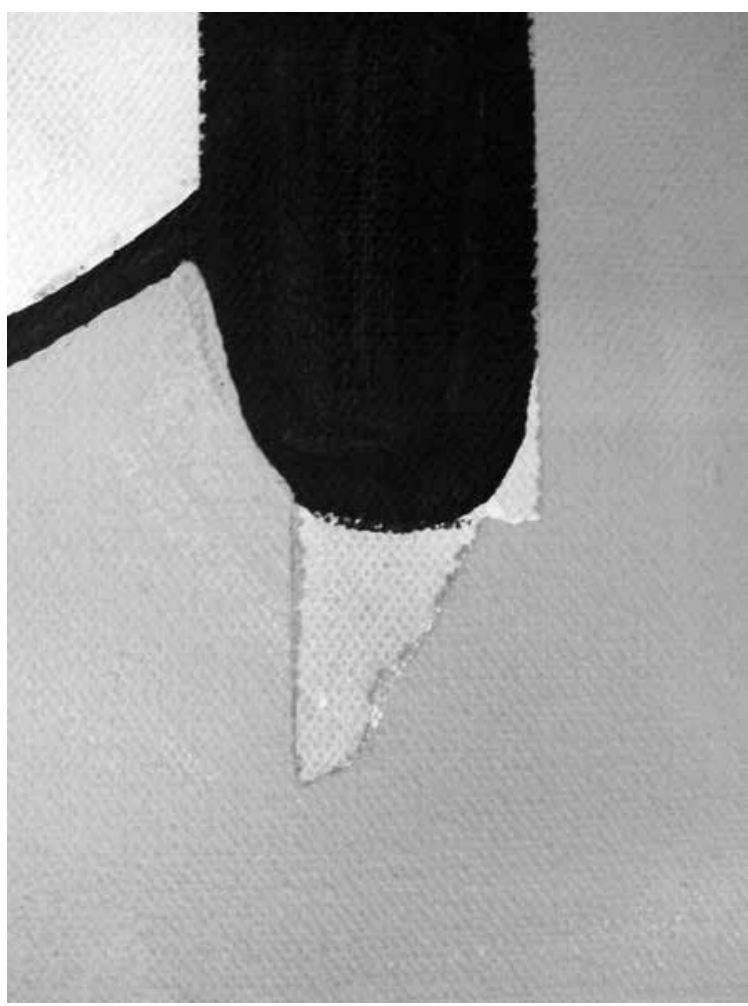

Imagen 17. Patricio Larrambebere (2002). Villa Ortuzar. Acrílico sobre tela, 40 × $50 \mathrm{~cm}$.

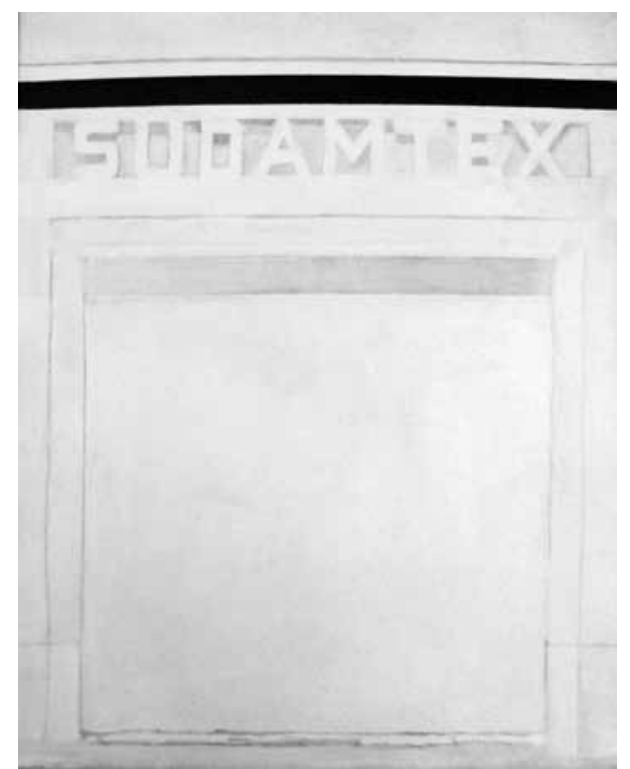

